\title{
The legal implications of prenatal diagnosis in Malaysia
}

\section{[version 1; peer review: 1 approved with reservations]}

Chee Ying Kuek (D)

Faculty of Law, Multimedia University, Malacca, 75450, Malaysia

\section{Abstract}

Background: Prenatal diagnosis enables detection of any disease or disability of the fetus during the pregnancy of a woman. Parents whose fetus is found to have a serious disorder from antenatal testing may terminate the pregnancy if it is permitted by the law or continue with the pregnancy to term. However, the chance of terminating a pregnancy may be denied if there is prenatal negligence by the medical practitioner in terms of diagnosis or failure to advise on the test results correctly. The purpose of this research is to examine the possible legal implications of prenatal diagnosis in Malaysia.

Methods: This study adopts doctrinal legal research in which the researcher examines statutes and decided cases in Malaysia, the United Kingdom (UK) and Singapore relating to abortion, wrongful birth and wrongful life claims, in order to determine the legal implications of prenatal diagnosis in Malaysia.

Results: In Malaysia, abortion following a prenatal diagnosis is only legally possible if the statutory criteria in the Penal Code are met. Abortion is illegal if it is not done for therapeutic purposes. A wrongful birth action brought by a woman who claims to be deprived of the opportunity to terminate her pregnancy may be successful in Malaysia, if it can be proven that a legal abortion could have been performed if not because of the prenatal negligence of the medical practitioner. However, a wrongful life action brought in the child's name for being allowed to be born with a disability may not be viable since the claim could hardly be established and it is against the public policy.

Conclusions: Theoretically, it is possible to bring a wrongful birth action resulted from negligence in prenatal diagnosis successfully in Malaysia, but the chance is relatively slim for wrongful life action.

\section{Keywords}

Abortion, disability, prenatal diagnosis, termination of pregnancy, wrongful birth, wrongful life

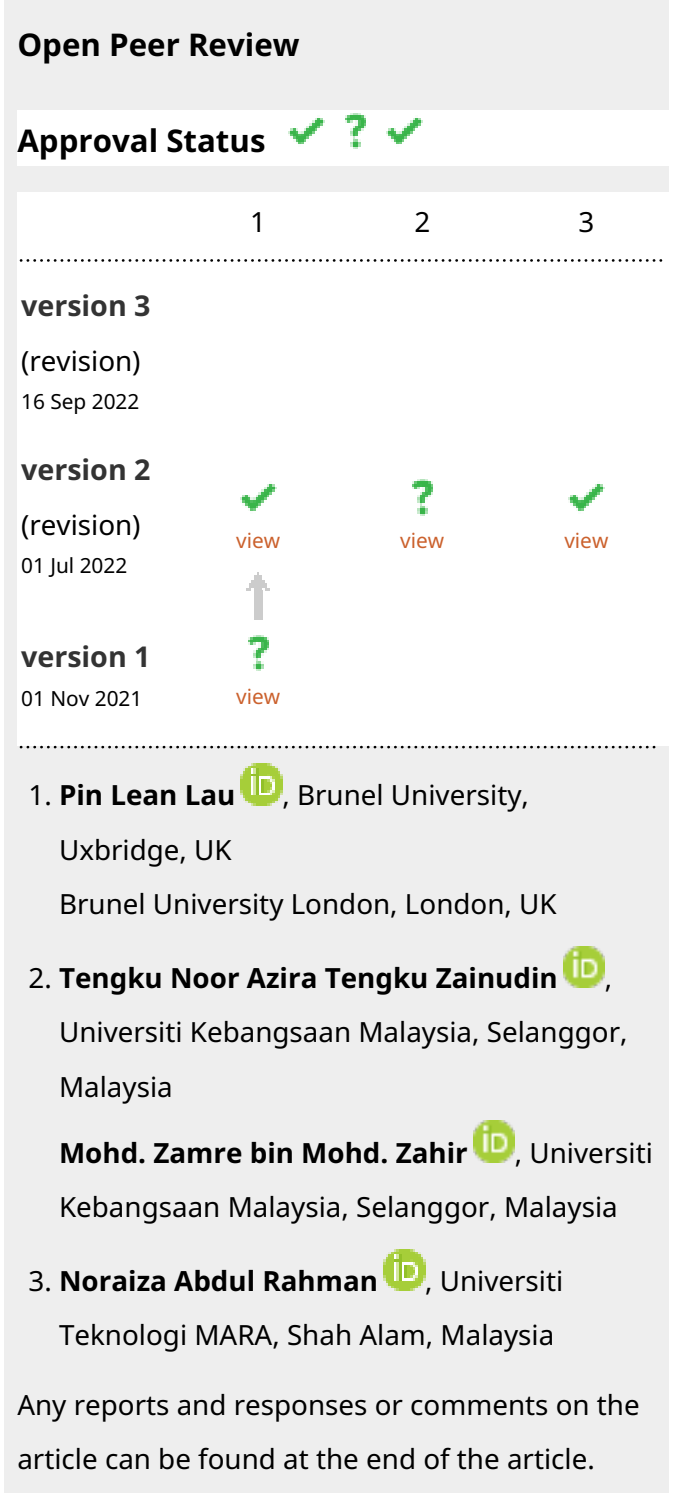




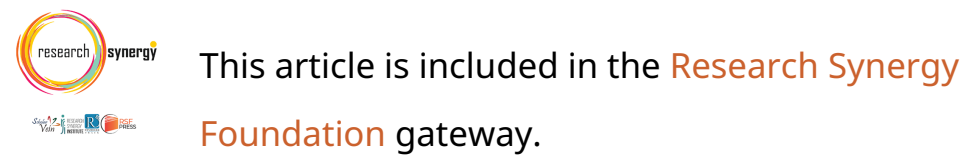

Corresponding author: Chee Ying Kuek (cykuek@mmu.edu.my)

Author roles: Kuek CY: Conceptualization, Data Curation, Formal Analysis, Methodology, Resources, Writing - Original Draft Preparation, Writing - Review \& Editing

Competing interests: No competing interests were disclosed.

Grant information: The author(s) declared that no grants were involved in supporting this work.

Copyright: (c) 2021 Kuek CY. This is an open access article distributed under the terms of the Creative Commons Attribution License, which permits unrestricted use, distribution, and reproduction in any medium, provided the original work is properly cited.

How to cite this article: Kuek CY. The legal implications of prenatal diagnosis in Malaysia [version 1; peer review: 1 approved with reservations] F1000Research 2021, 10:1103 https://doi.org/10.12688/f1000research.73231.1

First published: 01 Nov 2021, 10:1103 https://doi.org/10.12688/f1000research.73231.1 


\section{Introduction}

Prenatal diagnosis is offered to pregnant women with the aim of detecting any disease or disability of the fetus. The information about the serious genetic disorder or chromosomal abnormality detected in the fetus after the prenatal diagnosis may lead to the decision of terminating a pregnancy if it is permitted by the law. However, a prenatal diagnosis which is not properly conducted, or misinformation about the outcome of the prenatal tests, or a failure to advise a prospective mother about the serious medical condition of the fetus may result in the birth of a child with an undesirable disease, unexpected by the parents.

Previous studies have discussed the civil suits brought by parents or children against medical practitioners who were negligent in prenatal diagnosis, which led to the birth of children with severe disability or serious diseases, whom the parents would not have had if not because of the prenatal negligence. However, these studies mainly involved Western jurisdictions such as the United Kingdom (UK) (Fordham, 2004; Todd, 2005, 2019; Mason, 2007), Australia (Fordham, 2004; Todd, 2005, 2019), United States (Donavan, 1984; Hermanson, 2019; Haqq, 2020) but rarely in Asian countries although there was discussion on the position in Singapore (Fordham, 2005).

The purpose of this article is to examine the possible legal implications of prenatal diagnosis in Malaysia. Three aspects will be examined, namely the access to the abortion service, the possibility of wrongful birth and wrongful life claims in Malaysia. Discussion on these questions in the Asia region is relatively scarce especially in Malaysia due to the absence of reported judicial decisions in the country.

\section{Methods}

This article adopts doctrinal legal research or "black-letter law" approach which involves identifying, analysing and synthesizing the content of the law. This method requires the examination of the essential features of the relevant statutes and the court judgments, followed by the synthesis of the elements to construct a statement of the law on the matter in question (Hutchinson, 2013). Therefore, this study examined statutes, guidelines and decided cases in Malaysia, the UK and Singapore relating to abortion, wrongful birth and wrongful life claims. Searches for statutory provisions, cases and papers relating to abortion pursuant to prenatal diagnosis, wrongful birth and wrongful life cases were conducted in the databases and website namely LawNet, Westlaw Asia, Lexis Advance and Singapore Statute Online between 1 May 2021 and 14 July 2021. The search terms namely "abortion", "termination of life", "prenatal diagnosis", "wrongful birth" and "wrongful life" were used during the searches in these databases and website.

Statutory provisions in the Penal Code (Malaysia), Abortion Act 1967 (UK), Infant Life (Preservation) Act 1929 (UK), Termination of Pregnancy Act (Chapter 324) (Singapore) and case law were identified and analysed to explore the possible legal liabilities of medical practitioners in Malaysia relating to this kind of prenatal negligence, as compared to their counterparts in the UK and Singapore. The statutory provisions were interpreted by giving their ordinary meaning unless it is inappropriate in the light of the context and purpose (Sanson, 2016). The UK and Singapore were chosen for reference since these are common law countries which share the same legal system with Malaysia. In addition, there were reported cases of wrongful birth and wrongful life claims in these two jurisdictions. Four wrongful birth cases in the UK (2000-2001) and Singapore (2005) as well as two wrongful life cases in the UK (1982) and Singapore (2005) which were derived from the searches will be referred to in the discussion. These jurisdictions can offer experience and lessons to Malaysia since there is no reported case law in this aspect in Malaysia.

Ethical approval has been obtained from the Research Ethics Committee, Multimedia University (approval number: EA0482021).

\section{Results}

Abortion law in Malaysia

An induced abortion is generally prohibited under the Penal Code in Malaysia. Voluntarily causing a woman with child to miscarry constitutes a criminal offence. However, if it is performed by a registered medical practitioner who, in good faith, is of the view that the continuance of the pregnancy would risk the life of the pregnant woman or cause injury to her mental or physical health, greater than termination of pregnancy, then it is not an offence (Penal Code, s 312). An act with the intention to prevent the live birth of a child or cause the child to die after birth constitute an offence, unless it is done in good faith to save the mother's life (Penal Code, s 315). From the provisions of the Penal Code, some observation can be made. Firstly, abortion is not available upon request and a woman does not have a legally enforceable right to abortion in Malaysia. Secondly, the legality of an abortion rests upon the medical practitioner's views formed in good faith that continuance of pregnancy is posing greater risk than the termination of pregnancy. Thirdly, an abortion will be legal if the statutory criteria are met. Fourthly, a medical practitioner who performs an abortion will lose the legal protection if he is not acting in good faith. Therefore, a woman has no right to an abortion in Malaysia. However, if the medical practitioner 
decides that the women will suffer a greater risk of physical or mental health by having a child with serious fetal impairment and her health will be better served by termination of pregnancy, then termination of pregnancy will be lawful in such a circumstance. In Malaysia, termination of pregnancy is allowed until the $22^{\text {nd }}$ week of gestation or if the fetus is less than 500 grams (Ministry of Health Malaysia, 2012).

\section{Abortion law in the United Kingdom and Singapore}

In the UK, abortion is allowed if certain conditions are met. Two registered medical practitioners must form the opinion in good faith that any one of the four statutory grounds for abortion is satisfied: (a) the pregnancy shall not exceed 24 weeks of gestation and its continuance will cause a greater risk of injury to the physical or mental health of the woman or her existing child; (b) the abortion is needed to prevent grave permanent injury to the woman's physical or mental health; (c) the continuance of the pregnancy would pose a greater risk to the woman's life than the termination of pregnancy; (d) there is a substantial risk that the child to be born with physical or mental abnormalities (Abortion Act 1967, s 1(1)). It is also not an offence if a person causes the death of a child capable of being born alive, if it is done in good faith to preserve the mother's life (Infant Life (Preservation) Act 1929, s 1(1)).

As for Singapore, termination of pregnancy is lawful if it is performed by an authorised medical practitioner upon the pregnant woman's request and with her written consent (Termination of Pregnancy Act (Chapter 324), s 3(1)). However, abortion is not allowed if the pregnancy exceeds 24 weeks of gestation unless it is carried out "to save the life or to prevent grave permanent injury to the physical or mental health of the pregnant woman" (Termination of Pregnancy Act (Chapter 324), s 4(1)).

It would be observed that abortion is allowed on therapeutic and social grounds in the UK and Singapore. This is wider than the law in Malaysia which permits abortion on therapeutic reasons, to save the mother's life or to avoid greater injury to her mental or physical health should the pregnancy be continued.

\section{Discussion}

Wrongful birth

A wrongful birth action may be brought on the basis that the negligent prenatal diagnosis, or misinformation about the outcome of the prenatal tests, or a failure to advise on the fetal impairment by the medical practitioner has led to the birth of a child with significant physical or mental abnormalities. Such prenatal negligence could have deprived the woman of the chance of making informed consent for a legal abortion. The claim is for damages associated with rearing the child with impairment, as the parents would have terminated the pregnancy but for the negligence of those charged with prenatal testing or diagnosis.

A plaintiff for a wrongful birth action must establish the existence of a duty of care, breach of duty and the causation of damage. Proving a duty of care should not pose any problem because a medical practitioner who performs a prenatal test and/or provides diagnostic and interpretive service for the prenatal test owes a duty of care to the patient. As for the breach of duty, a plaintiff needs to prove that the defendant has acted below the reasonable standard of care expected from a medical practitioner. Finally, a plaintiff must establish a clear chain of causation between the breach of the duty and the harm caused to the plaintiff.

In cases where the prenatal negligence led to the birth of an affected child, the courts in the UK allowed or recognised the recovery of costs for the child's special needs or costs associated with the disability. However, the full costs of upbringing the child was denied. For instance, in the case of Rand v East Dorset Health Authority (2000), the antenatal test showed that the fetus was likely to have Down's syndrome but the doctors had negligently omitted to inform the parents about it. It was held that the claimants could recover damages in respect of economic loss caused by the child's disability. In Hardman v Amin (2001), a doctor failed to diagnose a rubella infection in a pregnant woman as he did not arrange seriological tests for her. The costs of providing for the disabled child's special needs were held to be recoverable relating to the degree of disability, and it was not governed by the parents' available resources. In the case of Lee $v$ Taunton and Somerset NHS Trust (2001), the radiologist negligently failed to detect spina bifida in the fetus when the ultrasound scan was conducted. The court followed Hardman and recognised the parent's right to recover the costs of meeting the disabled child's special needs.

The High Court of Singapore had a chance to hear a wrongful birth and wrongful life case brought by a mother and an infant in JU and Another $v$ See Tho Kai Yin (2005). The court dismissed the mother's claims. Applying the test in Bolam $v$ Friern Hospital Management Committee (1951), the court held that the medical practitioner had acted reasonably in managing the woman's pregnancy in accordance with the practice since it was too late for the woman to undergo a legal abortion at the material time (24-25 weeks of gestation). 
By reference to the cases in the UK and Singapore, it is theoretically possible for a woman to commence a wrongful birth action in Malaysia against the medical practitioner who commits prenatal negligence. However, the woman must be able to prove retrospectively that, a legal abortion could have been performed and if she had been informed or advised about the fetal abnormality, she would have terminated the pregnancy. Therefore, evidence which shows that the woman was very concerned with the possibility of fetal abnormality during her pregnancy would be helpful in supporting the claim. A woman who has an existing child affected by genetic disease or who has a history of mental health problem may prove through an expert witness that she is at risk of facing greater mental health problem due to the unwanted pregnancy of a prospective child with severe genetic disease. Nevertheless, wrongful birth action is expected to be rare in Malaysia due to the cultural and religious reasons which tend to be more pro-life than pro-choice (Low, Tong, and Gunasegaran, 2013).

\section{Wrongful life}

A wrongful life action is brought by or on behalf of a child born with disability or abnormalities in circumstances that if the medical practitioner's negligence had not occurred, the child would not have been born at all. Such a claim may arise when the fetus's abnormality was not detected by a prenatal test due to negligence.

In the leading English case of McKay v Essex AHA (1982), the wrongful life claim was dismissed. The court held that the doctor did not owe a legal duty under the Abortion Act 1967 to the fetus to terminate its life. The plaintiff's claim was contrary to the public policy as it violated the sanctity of human life. Furthermore, it is impossible to measure appropriate damages. In the wrongful life claim in JU and Another $v$ See Tho Kai Yin (2005), the High Court of Singapore adopted the common law position in the UK, Canada and Australia and rejected the claim.

If a wrongful life claim is commenced in Malaysia, it is very likely to fail as well. It would be against the public policy to rule that a disabled child should not have been born as it devalues the life of a disabled person and violates human dignity. It is also impossible for the disabled child to establish that he or she would have been better off not to have existed. The basic principle of tort compensation is to restore the plaintiff to the original state in the absence of the defendant's negligence. However, in the case of wrongful life, there is difficulty in quantifying damages or compensation to the disabled child by comparing a life with serious disabilities with a state of non-existence.

\section{Limitation}

This study sought to fill the gap of the prior academic work in which the legal implications of prenatal diagnosis were hardly discussed in the Asian context, particularly in Malaysia. However, the fact that there is no reported or decided case on wrongful birth and wrongful life in Malaysia has limited the study. This is because the analysis of the legal implications of prenatal diagnosis in Malaysia can only be based on the local legislation and guideline, as well as reference to the decided cases of other jurisdictions which have the persuasive value.

\section{Conclusions}

Theoretically, a wrongful birth action brought by a woman who claims to be deprived of the opportunity to terminate her pregnancy may be successful in Malaysia. It needs to be proven that a legal abortion could have been performed and the woman would have chosen to terminate the pregnancy, if not because of the medical practitioner's prenatal negligence. However, such action may be rare in Malaysia considering the cultural and religious reasons.

In contrast, a wrongful life action brought in the child's name for being allowed to be born with a disability would most likely be rejected. This is because such action appears to undermine human life and it is against the public policy. In addition, the claim of being harmed by being born could hardly be established or recognised in law.

\section{Data availability}

Underlying data

Figshare: Legal implications of prenatal diagnosis. https://doi.org/10.6084/m9.figshare.15167907.v1 (C Y Kuek, 2021).

This project contains the following underlying data.

- my Penal Code ss 312, 315.docx

- $\quad$ sg Ju and Another v See Tho Kai Yin (2005) SGHC 140.docx

- sg Termination of Pregnancy Act, s 3.docx

- uk Abortion Act 1967, s 1.rft 
- uk Bolam v Friern Hospital Management Committee (1957) 1 WLR 582.rtf

- uk Hardman v Amin 59 BMLR 58.docx

- uk Infant Life (Preservation) Act 1929, s 1.rtf

- uk Lee v Taunton and Somerset NHS Trust (2001) 1 FLR 419.docx

- uk McKay and Another v Essex Area Health Authority.docx

- uk Rand v East Dorset Health Authority 56 BMLR 39.docx

Data is available under the terms of the Creative Commons Zero "No rights reserved" data waiver (CC0 1.0 Public domain dedication).

\section{Acknowledgements}

The author would like to thank Siti Hasmah Digital Library for the access to the databases which enable the research to be conducted smoothly.

\section{References}

Abortion Act 1967: (United Kingdom)

Bolam v Friern Hospital Management Committee: 1957.1 WLR 582.

Donavan P: Wrong birth and wrongful conception: the legal and moral issues. Fam. Plan. Perspect. 1984; 16(2):

64-69.

PubMed Abstract | Publisher Full Text

Fordham M: Blessing or burden? Recent developments in actions for wrongful conception and wrongful birth in the U.K. and Australia. Singap. J. Leg. Stud. 2004; 2004(2): 462-483.

Fordham M: A life without value? JU and another v See Tho Kai Yin. Singap. J. Leg. Stud. 2005; 2005(2): 395-406.

Haqq LI: Reconsidering wrongful birth. Notre Dame Law Review Reflection. 2020; 95(5): 177-189.

Hardman v Amin: 2001.59 BMLR 58.

Hermanson $\mathrm{H}$ : The right recovery for wrongful birth. Drake Law Rev. 2019; 67(2): 513-559.

Hutchinson T: Doctrinal research: researching the jury. Watkins $D$, Burton M, editors. Research methods in law. New York: Routledge; 2013; (pp. 7-34).

Infant Life (Preservation) Act 1929: (United Kingdom).

JU and Another v See Tho Kai Yin: 2005.4 SLR(R) 96.
Kuek CY: Legal implications of prenatal diagnosis. figshare. Dataset. 2021.

Publisher Full Text

Lee v Taunton and Somerset NHS Trust: 2001.1 FLR 419.

Low WY, Tong WT, Gunasegaran V: Issues of safe abortions in Malaysia: Reproductive rights and choice. University of Malaya/United Nations

Population Fund (UNFPA); 2013.

Mason JK: The troubled pregnancy: legal wrongs and rights in reproduction. Cambridge University Press; 2007.

McKay $v$ Essex AHA: 1982.1 QB 1166.

Ministry of Health Malaysia: Guideline on termination of pregnancy (TOP) for hospitals in the Ministry of Health. Putrajaya, Malaysia: Ministry of Health Malaysia; 2012

Penal Code: (Malaysia).

Rand v East Dorset Health Authority: 2000.56 BMLR 39.

Sanson M: Statutory Interpretation. Victoria, Australia: Oxford University Press; 2016.

Termination of Pregnancy Act (Chapter 324): (Singapore).

Todd S: Wrongful conception, wrongful birth and wrongful life. Sydney Law Rev. 2005; 27(3): 525-542.

Todd S: Common law protection for injury to a person's reproductive autonomy. Law Quarterly Rev. 2019; 135(4): 635-659. 


\title{
Open Peer Review
}

\section{Current Peer Review Status: ?}

\section{Version 1}

Reviewer Report 03 December 2021

https://doi.org/10.5256/f1000research.76871.r99451

(C) 2021 Lau P. This is an open access peer review report distributed under the terms of the Creative Commons Attribution License, which permits unrestricted use, distribution, and reproduction in any medium, provided the original work is properly cited.

\author{
Pin Lean Lau \\ 1 Brunel Law School, Brunel University, Uxbridge, UK \\ ${ }^{2}$ Centre for Artificial Intelligence: Social \& Digital Innovations, Brunel University London, London, \\ UK
}

Specific comments and suggestions to the author have been provided in a copy of the document, highlighted in yellow. Please also refer to the copy of the document which highlights these comments and suggestions, in addition to the general feedback below:

1. For example, in the introduction, the phraseology "legal implications of prenatal diagnosis" is much broader than the trajectory of the article suggests. As such, I have suggested that disclaimers or a narrow conception be explained, that the legal implications are considered specifically from the viewpoint of abortions, wrongly life, and wrongful birth claims.

2. In the final paragraph of the section addressing abortion in the UK and Singapore, it would be helpful for the author to provide more clarity as to what "social grounds" would encompass, and specifically how this differs from the situation in Malaysia. The recommendation is not to use "social grounds" as it seems to denote a form of casualness instead, it is more helpful to specify what these "social grounds" are, and to contrast this against Malaysia.

3. Under the Discussion section on Wrongful Birth, it would provide greater clarity for the author to explain that the duty of care of a medical professional arises under the tort of negligence in common law jurisdictions. On the assumption that this article may be read beyond the scope of Malaysia and its neighbours, this would provide clarity for readers from civil law jurisdictions that do not strictly speaking, encounter medical negligence as a tortious cause of action.

4. Under the same section, it would be good to highlight the Bolam and Bolitho cases in the UK, as these would be critical starting points of discussion of medical negligence in the UK, before theorizing on the wrongful birth claims. It would also be appropriate to reflect on Montgomery $v$ Lanarkshire Health Board in the UK, as this case seems to suggest a 
displacement of the Bolam test in the UK (although it does not expressly overrule the Bolam case).

5. The same strand of argument may be applied in the consideration of Malaysia's situation i.e. Foo Fio Na v Dr Soo Fook Mun which also displaces the Bolam test - and contrasted this against the Singaporean position which continues to affirm the goodness of the Bolam principles. These would add a deeper dimension to the article in terms of reflecting the struggles and applicability even in the UK and Singapore. I also highlighted that even before considering wrongful birth or life in Malaysia, it is worth looking at medical negligence as an umbrella overview- and determining the possibility of wrongful life and birth claims being sought under this heading.

6. The Discussions on Wrongful Life seem to be a little sparse in comparison with Wrongful Birth. I would suggest expanding on McKay v Essex and JU and Another in allowing a more nuanced discussion of wrongful life claims. It is also vital to discuss Evie Toombes v Dr Philip Mitchell (2020) as this case provides to us a renewed understanding as to how courts may consider wrongful life cases. In fact, Evie Toombes is distinguished from McKay, although its real outcome was based on the issue of causation. I would highly recommend that Evie Toombes be included in the narrative too.

Is the work clearly and accurately presented and does it cite the current literature? Partly

Is the study design appropriate and is the work technically sound? Yes

Are sufficient details of methods and analysis provided to allow replication by others? Yes

If applicable, is the statistical analysis and its interpretation appropriate? Not applicable

Are all the source data underlying the results available to ensure full reproducibility? No source data required

Are the conclusions drawn adequately supported by the results? Partly

Competing Interests: No competing interests were disclosed.

Reviewer Expertise: European, international, and comparative law for genome editing (with a focus on pre-implantation genetic diagnosis, reproductive technologies and women's bodies; and the proliferation of virulent gene-edited pathogens and global bio-security); propertization and commodification studies of genetic materials and biomedical technologies; and the ethico-legal governance for artificial intelligence (AI) systems (with a focus on protection of fundamental rights, spatial 'body citizenship' and bio-constitutional implications of the AI-augmented biological 
human body.

I confirm that I have read this submission and believe that I have an appropriate level of expertise to confirm that it is of an acceptable scientific standard, however I have significant reservations, as outlined above.

\section{Author Response 27 Jun 2022}

Chee Ying Kuek, Multimedia University, Malacca, Malaysia

The author would like to thank Dr Pin Lean Lau for her helpful comments.

This revision (version 2) addressed the comments and suggestions raised by Dr Pin Lean Lau. Amendments were made to the Introduction by adding the disclaimer as suggested. Minor amendments were made to the Methods by adding one statute and one new case, in which the judgment of the case was not available at the time of initial writing. Under the section "Abortion law in the United Kingdom and Singapore", explanation was added on what was meant by "social ground" as referred by commentators. Under the Discussion section on "Wrongful Birth", explanation was added in respect of a medical professional's duty of care under the tort of medical negligence, the standard of care for diagnosis and treatment under the Bolam test which was subsequently revisited by Bolitho; and the "prudent patient" test for duty to advise in Montgomery case. The current position of Malaysia in respect of the standard of care was briefly pointed out through the Federal Court cases of Zulhasnimar and Dr Hari Krishnan. As for the Discussion section for "Wrongful Life", the discussion of the Congenital Disabilities (Civil Liability) Act 1976 (the 1976 Act) and the new case of Toombes $v$ Mitchell have been added. However, it was made clearer that Malaysia is still likely to adopt the common law position since Malaysia does not have similar statute like the 1976 Act.

Competing Interests: The author does not have any competing interests to disclose. 
The benefits of publishing with F1000Research:

- Your article is published within days, with no editorial bias

- You can publish traditional articles, null/negative results, case reports, data notes and more

- The peer review process is transparent and collaborative

- Your article is indexed in PubMed after passing peer review

- Dedicated customer support at every stage

For pre-submission enquiries, contact research@f1000.com 